\title{
ALTERNATIVES FOR THE PRODUCTION OF LEVULINIC ACID OBTAINED FROM BIOMASS
}

\author{
Lucas A. dos Santos ${ }^{a}$, Gabrielle das V. Fraga ${ }^{a}$, Danilo Aguiar Pontes ${ }^{\mathrm{a}}$, Leila M. A. Campos ${ }^{\mathrm{b}}$, Luiz A. M. Pontes ${ }^{\mathrm{a}, \mathrm{c}}$ and \\ Leonardo S. G. Teixeira ${ }^{\mathrm{d}, *,(1)}$ \\ aDepartamento de Engenharia Química, Universidade Federal da Bahia, 40210-630 Salvador - BA, Brasil \\ ${ }^{b}$ Escola de Ciências Exatas e Tecnológicas, Universidade Salvador, 41940-560 Salvador - BA, Brasil \\ 'Instituto Brasileiro de Tecnologia e Regulação, 41770-235 Salvador - BA, Brasil \\ 'Instituto de Química, Universidade Federal da Bahia, 40170-115 Salvador - BA, Brasil
}

Recebido em 27/02/2021; aceito em 11/05/2021; publicado na web em 04/06/2021

\begin{abstract}
Levulinic acid is a reactive polar organic compound deemed as a building block for several products with relevant applications, replacing traditional substances in the petrochemical industry. Considered a platform molecule, levulinic acid is industrially produced from the acid hydrolysis of biomass - mainly plant-based - using hydrochloric or sulfuric acid in homogenous catalysis. However, considering the World Market for levulinic acid is expected to reach US\$ 71.9 million in 2027, growing annually at $14.1 \%$, and its applications in agriculture, pharmaceuticals, plasticizers, cosmetics, and food additives, the development of alternative production processes is sought. Hence, a survey was performed on publications considering the alternatives for biomass-based levulinic acid production processes: I) alternative homogenous catalysts to avoid using noble materials in the reactor; II) heterogeneous catalysis to facilitate and reduce the catalyst's separation and recovery costs; III) ionic liquids, exploiting their high solvency, stability, and catalytic capacity. Additionally, biomass alternatives for obtaining levulinic acid are presented, showing that other agricultural residues and animal biomass options are being considered, targeting process flexibilization while reducing costs and producing derivatives at more competitive prices. Thus, it can be stated that levulinic acid is an important platform molecule for biorefineries' economics, replacing fossil fuels with renewable raw materials.
\end{abstract}

Keywords: biomass; biorefinery; building block; levulinic acid.

\section{INTRODUCTION}

Environmental awareness has directed research to the obtainment of ecofriendly chemicals from biomass. ${ }^{1,2}$ In the $21^{\text {st }}$ century, the focus has been on the efficient recovery of sugars contained in biomass, through cellulose and hemicellulose hydrolysis, followed by the chemical conversion of such sugars into high added-value products. ${ }^{3,4}$

Levulinic acid (LA), also known as 4-oxopentanoic acid ${ }^{5}$ and classified as a ketoacid, was listed as a platform molecule of interest by the U.S. Department of Energy. Platform molecules present several chemical functions, and are the basis for new products obtained from biomass within the concept of biorefineries. ${ }^{6,7}$

LA is industrially obtained by the dehydration of six-carbon carbohydrates using acid homogeneous catalysis, with an average yield of $70 \%$ when compared to the theoretical value. ${ }^{8,9}$ However, new routes involving heterogeneous catalysts and ionic liquids (ILs) have been studied. Due to its high reactivity, LA is a precursor to several derivatives, such as $\gamma$-valerolactone, diphenolic acid, $\delta$-amino levulinic acid, and 2-methyl tetrahydrofuran. ${ }^{10-12}$

It is estimated that, in 2020, the World Market for LA has reached US\$28.6 million, and is projected to reach US\$ 71.9 million in 2027 , at a compound annual growth rate (CAGR) of $14.1 \% .{ }^{13}$ The price of LA was US\$3.80 per $\mathrm{kg}(2020),{ }^{14}$ yet the industrial sector expects that production costs will be reduced, and thus achieve better results in the manufacturing of LA derivatives. ${ }^{15}$ The largest LA Market (30\% of total) is in the production of fertilizers and pesticides for agriculture, followed by applications in pharmaceuticals and plasticizers (18\%). Cosmetics and food additives correspond to $15 \%$ and $14 \%$ of the LA market, respectively. Other applications correspond to $5 \%{ }^{16}$

*e-mail: lsgt@ufba.br
Among the factors that should heat the LA market, the growing application of pesticides in Asia (the largest world market) is highlighted, and the greater consumption of cosmetics and pharmaceuticals by the European market, currently the secondlargest consumer market of LA. ${ }^{16}$ Most LA production facilities are located in China, meeting the domestic consumption of fertilizers and pesticides. ${ }^{13,17}$ Perspectives on production cost reduction in the manufacturing of LA derivatives exist, with the development of new research and processes, besides upscaling and increase in the varieties of LA applications and its derivatives..$^{15,18}$

Considering the importance of LA as a precursor to innumerous high added-value chemical derivatives, this paper performs a critical analysis, from articles, patents, and consulting firms' reports, on several LA synthesis routes, and of its industrial processes from biomass.

\section{Levulinic acid properties and production routes}

LA presents the molecular formula $\mathrm{C}_{5} \mathrm{H}_{8} \mathrm{O}_{3}$, whose structure contains a carboxyl and a carbonyl group (Figure 1). Some of its physical-chemical properties are displayed in Table 1.

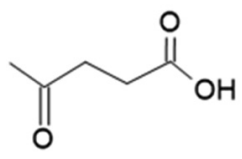

Figure 1. Molecular structure of levulinic acid

One LA synthesis petrochemical route is the conjugate addition of nitroethane to acrolein in the presence of $\mathrm{Al}_{2} \mathrm{O}_{3}$ to form 4-nitropentanal. ${ }^{19,20} 4$-Nitropentanal is then oxidated in the presence of $\mathrm{H}_{2} \mathrm{O}_{2}-\mathrm{K}_{2} \mathrm{CO}_{3}$ to form LA (Figure 2a). Through another LA route 
Table 1. Physical-chemical properties of levulinic acid

\begin{tabular}{lc}
\hline Property & Value \\
\hline Molar mass $\left(\mathrm{g} \mathrm{mol}^{-1}\right)$ & 116.12 \\
Density $\left(\mathrm{kg} \mathrm{m}^{-3}\right)$ & $1136\left(\right.$ at $\left.25^{\circ} \mathrm{C}\right)$ \\
Melting point $\left({ }^{\circ} \mathrm{C}\right)$ & 33 \\
Boiling point $\left({ }^{\circ} \mathrm{C}\right)$ & 245 \\
Flashpoint $\left({ }^{\circ} \mathrm{C}\right)$ & 98 \\
\hline
\end{tabular}

from oil, maleic acid is used as feedstock (Figure 2b), which is then converted in acidic media into its respective ester, and, with the breakage of the double bond between carbons, acetyl succinate is obtained, followed by ethyl levulinate, and, after hydrolysis in the presence of acid or base, LA is formed. ${ }^{21}$

One of the main characteristics of biomass is being renewable, and an important alternative for obtaining chemicals usually synthesized from petroleum. ${ }^{22}$ Both LA synthesis routes from biomass use lignocellulose as feedstock, and depend on the cellulose and hemicellulose content in biomass. Pretreatment with a diluted acid $\left(\mathrm{H}_{2} \mathrm{SO}_{4}\right)$ is necessary, aiming at destructuring lignocellulosic biomass and reducing its recalcitrance, allowing for the depolymerization of cellulose into glucose. While still in the presence of mineral acid, the dehydration of glucose occurs, with the afterward formation of 5-hydroxymethyl furfural (HMF), followed by rehydration in LA and formic acid (FA) (Figure 3a). ${ }^{23}$ In the latter route, xylose, a sugar obtained from the depolymerization of hemicellulose, is dehydrated into furfural, which is then hydrogenated in the presence of a metal so that furfuryl alcohol is obtained. Thence, the hydration in acidic media with ring-opening for forming LA occurs (Figure $3 b$ ). ${ }^{23}$

\section{Scientific publications and patents on levulinic acid mapping}

An overview in LA production technologies using biomass and their respective applications is presented, made possible by collecting data from scientific articles and book chapters, through the Science Direct (www.sciencedirect.com) platform, in the period from 1996 to 2020, and patent search performed through the Derwent Innovations Index (www.derwentinnovationsindex.com) database in the period from 1963 to 2020.

Within the scientific articles data bank, the keyword "levulinic acid" was used, followed by "and", combined with the words that define the use of LA from biomass. The terms used in combination with the keyword "levulinic acid" were "biomass" or "biorefinery"

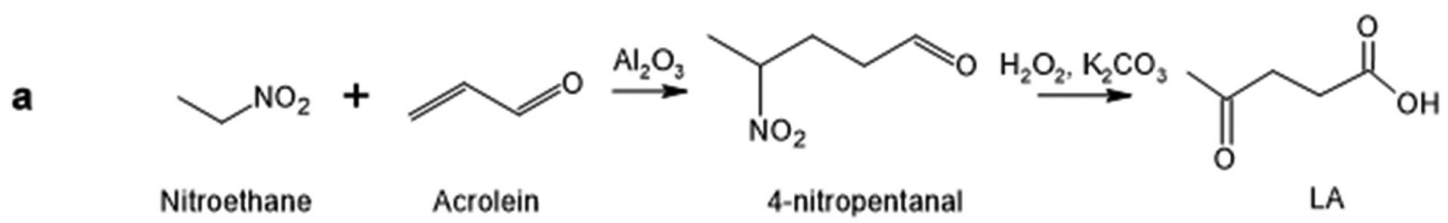

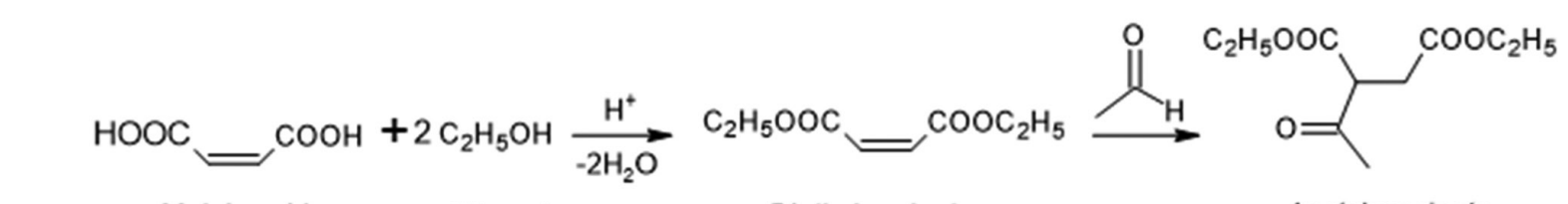

b

$\begin{array}{lll}\text { Maleic acid Ethanol Diethyl maleate } & \text { Acetylsuccinate }\end{array}$<smiles>CC[CH+]C(=O)CCC(=O)CC(C(=O)OCC)C(CC(=O)OCC)C(C)=O</smiles>

Acetylsuccinate

Ethyl levulinate

LA

Figure 2. Petrochemical routes for the obtainment of levulinic acid from: a) nitroethane and acrolein; $b$ ) maleic acid.20,21

a<smiles>OCC1O[C@H](O)[C@@H](O)[C@H](O)[C@H]1O</smiles>

Glucose

b

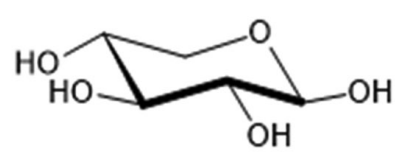

Xylose

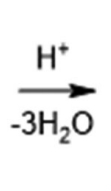

HO<smiles>O=Cc1ccc(CO)o1</smiles>

HMF

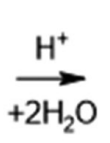

$\underset{-3 \mathrm{H}_{2} \mathrm{O}}{\stackrel{\mathrm{H}^{+}}{\longrightarrow}}$

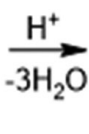<smiles>C[14CH3]</smiles>

Furfural<smiles>OCc1ccco1</smiles>

Furfuryl alcohol<smiles>CC(=O)CCC(=O)O</smiles>

LA

FA<smiles>CC(=O)CCC(=O)O</smiles>

LA

Figure 3. Main paths for levulinic acid formation from biomass, having as precursors: a) glucose, b) xylose $e^{21}$ 
or "building block", yielding 3,454, 1,170, and 979 scientific publications, respectively. In order to refine the search, the keywords "levulinic acid" and "biomass" were used with the terms "catalysis" or "ionic liquid", resulting in 1,510 and 1,046, respectively. Regarding patents, the keywords used in the search were "levulinic acid" followed by "and", and the denominations "biomass" or "biorefinery" or "building block" whose dataset yielded 301, 4, and 26 patents, respectively.

According to the data displayed in Figure 4, from 2007 onwards, there was a growth in the number of publications related to LA, due to the reports released by the U.S. Department of Energy on platform molecules, ${ }^{24,25}$ with a more significant increase from 2010, with the presentation of the concept of biorefinery.

In order to analyze the prospection results, the articles were separated by substrate type, and catalysis type used for the obtainment of LA (Figure 5).

The substrates from plant-based residues, such as bamboo, pine, and eucalyptus correspond to $21 \%$ of publications, just as much as agricultural products like bark, stalk or straw from rice, sugarcane, and maize, which also represent $21 \%$ of publications, demonstrating that the production of LA is associated to large plantations. Nine percent of publications used commercial cellulose as a substrate, much the same as $30 \%$ used commercial sugars, like glucose, fructose, and cellobiose. The use of commercial sugars has the advantage of accelerating the obtainment of LA, for the biomass pretreatment and cellulose and hemicellulose hydrolysis steps are made unnecessary, shifting the focus of the study to analyses related to the mechanism, yield, catalyst, and reaction conditions. Nevertheless, the use of sugars from biomass requires pretreatment and hydrolysis steps, fundamental to obtain higher LA yields. The substrates indicated as "other" correspond to $19 \%$ of publications referent to LA, and encompass all compounds not included in the four main criteria; that is, animal-based products (chitin, chitosan, and glucosamine), and residue found in garbage such as paper and wasted food.

Regarding the process, homogeneous and heterogeneous catalysis were used in $38 \%$ and $45 \%$ of the published articles, respectively. It can be noted that there is scientific interest in the search for heterogeneous catalysts that may replace the use of mineral acids $\mathrm{H}_{2} \mathrm{SO}_{4}$ and $\mathrm{HCl}$, used in homogeneous systems. The use of ionic liquids appears in $17 \%$ of publications relative to LA production. These compounds have been used as solvents or catalysts for their low vapor pressure, thermal stability, besides their solvency in several substances, ${ }^{26}$ for which they have attracted the attention of researchers in recent years, increasing the number of publications on

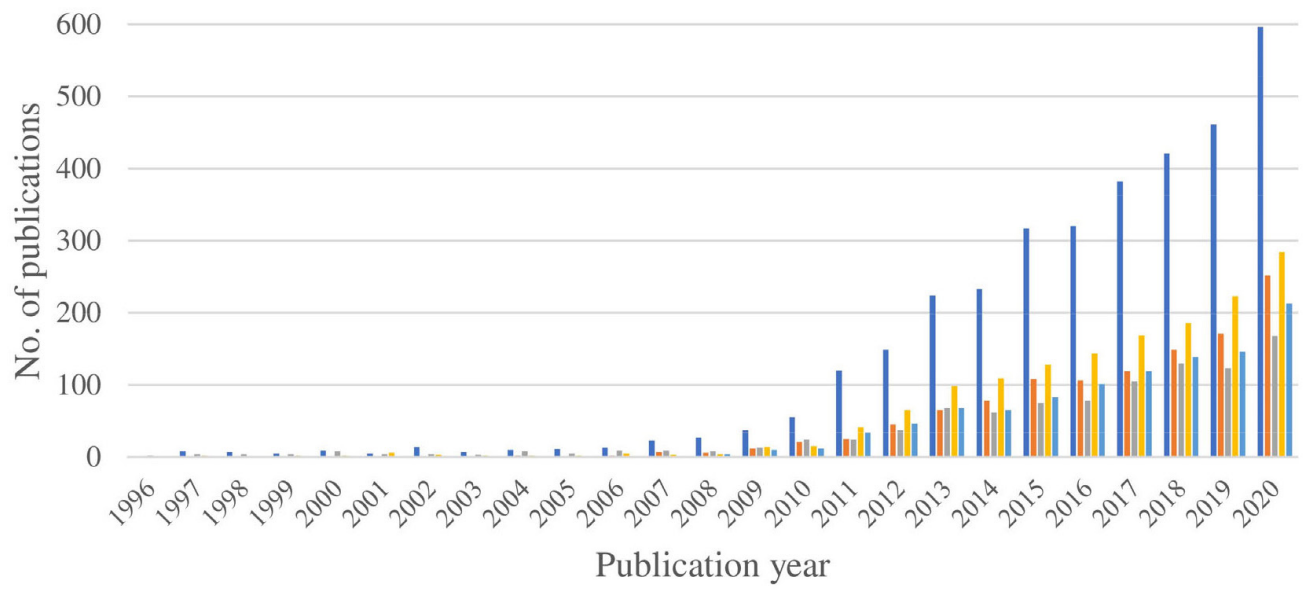
- levulinic acid AND biomass
- levulinic acid AND biorefinery
- levulinic acid AND building block
- levulinic acid AND biomass AND catalysis
- levulinic acid AND biomass AND ionic liquid

Figure 4. Number of articles per year of publication in the Science Direct platform
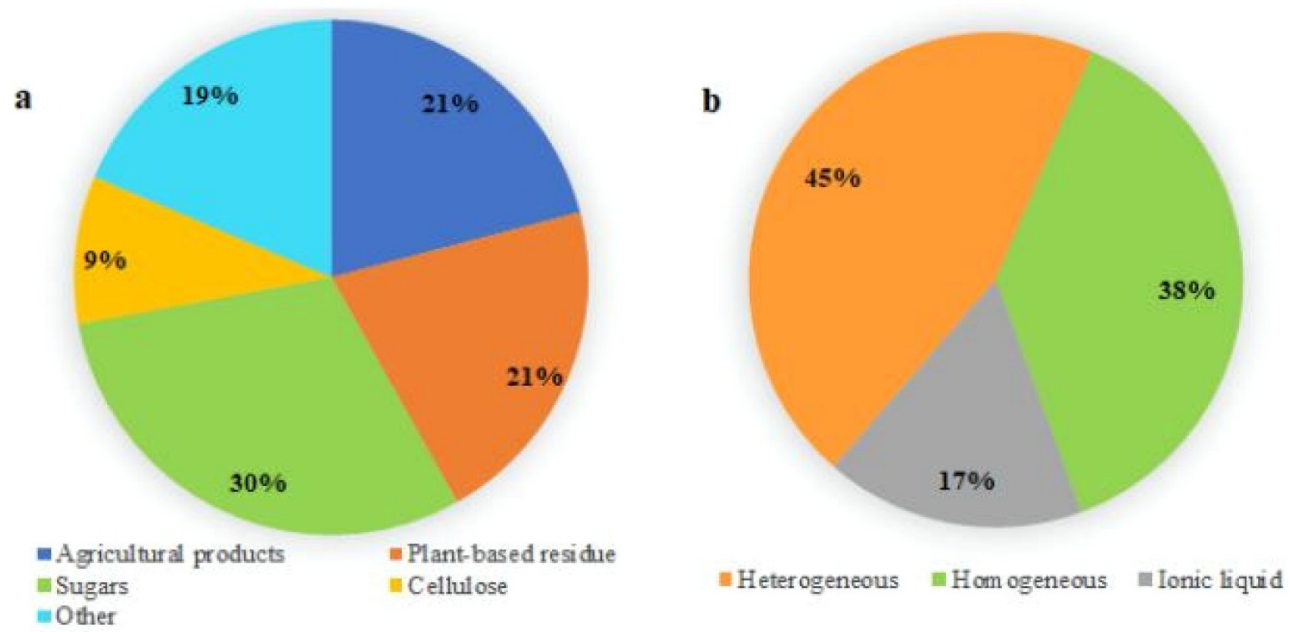

Figure 5. Distribution of publications relative to levulinic acid synthesis segregated in terms of type of used: a) substrate, b) catalysis 
these substances. ${ }^{27}$ The published works on the synthesis of LA from biomass were carried out, in general, on a bench scale. Laboratoryscale experiments are important for studying possible ways to expand LA production on a commercial scale.

The countries with the largest number of patents related to LA synthesis are the United States, China, Brazil, and India, together corresponding to $67 \%$ of prospected patents in the Derwent Innovations Index. This fact is explained by the large agricultural production and territorial extension of those countries, since these nations are among the five greatest in agricultural land availability, according to the Food and Agriculture Organization of the United Nations (FAO), ${ }^{28}$ thus having the greatest biomass availability.

\section{Levulinic acid synthesis from biomass technologies}

The LA obtainment process, besides depending on reaction conditions, varies with the substrate chosen as feedstock, the composition of biomass, and concentration of six-carbon sugars present in biomass. ${ }^{23}$ Since cellulose and hemicellulose are present in plant-based organic matter in large quantities, the obtainment of LA can be performed from several kinds of feedstock, including biomass residue.

LA synthesis consists primarily of the biomass pretreatment with mineral acids, leading to the depolymerization of cellulose, turning the reactional medium rich in glucose. Afterwards, glucose is dehydrated through acid catalysis with heating, transforming into HMF, and then into LA and FA. This process is preferable in relation to the hemicellulose route because furfural is quite reactive, forming more FA and other byproducts. ${ }^{23}$ Heterogeneous and homogeneous processes, including those using ionic liquids, have been explored in the proposal of LA obtainment procedures.

\section{Processes that use homogeneous catalysis}

Strong Brønsted acids in the liquid phase are used to hydrolyze biomass. ${ }^{29}$ These processes take place in reactors manufactured using special materials due to the reactional media corrosiveness. Furthermore, there is the necessity of separating and recovering the acid, being the optimization of these operations for LA production cost reduction fundamental. ${ }^{19,30,31}$ Table 2 showcases a comparison of several substrates and reaction conditions, while employing homogeneous catalysts in the obtainment of LA. ${ }^{8,32-54}$

Glucose and fructose $\left(180 \mathrm{~g} \mathrm{~mol}^{-1}\right)$ are the most used feedstock in homogeneous processes, and the theoretical yield in LA for the hydrolysis of these sugars is $64.4 \% .{ }^{49}$ Experimentally, from glucose, yields over $40 \%$ were obtained, working in the liquid phase and temperatures between $150{ }^{\circ} \mathrm{C}$ and $180{ }^{\circ} \mathrm{C}$, with residence times between 15 min and $8 \mathrm{~h}$, using, as a catalyst, $\mathrm{H}_{2} \mathrm{SO}_{4}$ or $\mathrm{HCl} .{ }^{45}$ With fructose, LA yields were up to $47 \%$, at $140{ }^{\circ} \mathrm{C}$ and $10 \mathrm{~min}$, using $\mathrm{H}_{2} \mathrm{SO}_{4}$ as a catalyst. ${ }^{42}$ Glucose and fructose conversion varied between $68 \%$ and $100 \%$, having, as the main byproduct, humins, which are solid polymers with a bituminous aspect, and insoluble in LA, that can cause blockage and fouling in piping and industrial equipment. ${ }^{23,55}$ Fructose is more expensive than glucose, yet reaction conditions are milder, since it is more selective to the formation of $\mathrm{HMF} .{ }^{42}$ It should be pointed out that higher temperatures favor the formation of humins, making the process more costly. ${ }^{15}$ The yield in humins can reach $40 \%$, significantly decreasing the amount of LA formed. ${ }^{23,56-58}$

Another kind of feedstock used as a substrate is cellulose, with a theoretical yield of $71.6 \% .^{59}$ Experimentally, the highest yield $(42,4 \%)$ was achieved at $180{ }^{\circ} \mathrm{C}$, reactional time of $11 \mathrm{~min}$ and $\mathrm{HCl}$ as a catalyst, which represents $59 \%$ of the theoretical yield. When the same reaction is carried out at $200{ }^{\circ} \mathrm{C}$, the yield reduces to $38 \%$, due to the formation of humins. ${ }^{38}$ The main advantage of cellulose over glucose and fructose is process economics, since its commercial value is significantly lower. ${ }^{60}$

The most used homogeneous catalysts in the reactions were sulfuric and hydrochloric acid, because besides being low-cost, reactional times were shorter than other studied acids. ${ }^{38} \mathrm{LA}$ synthesis from glucose using a mixture of $\mathrm{H}_{3} \mathrm{PO}_{4}$ and $\mathrm{CrCl}_{3}$, at $170{ }^{\circ} \mathrm{C}$, for $4.5 \mathrm{~h}$, had a yield of $32.1 \%{ }^{46}$ However, reactional times were reduced to 30 min when using $\mathrm{HCl}$ or $\mathrm{H}_{2} \mathrm{SO}_{4}$, with yields of $31.4 \%$ and $26.4 \%$, respectively. Methane sulfonic acid, $\mathrm{CH}_{3} \mathrm{SO}_{3} \mathrm{H}$, showed potential for LA production. Using glucose as a substrate, at $180^{\circ} \mathrm{C}$, for $15 \mathrm{~min}$, the yield was $40.7 \%,{ }^{45}$ which can be explained by the fact that $\mathrm{CH}_{3} \mathrm{SO}_{3} \mathrm{H}$ is a strong acid, which reduces humin formation and parallel reactions. Its disadvantage lies in its high cost when compared to sulfuric and hydrochloric acid.

In natura biomass and its derivatives have been used as feedstock for the direct production of LA. The higher the cellulose content in the substrate (TC), measured in $\% \mathrm{~g} \mathrm{~g}^{-1}$, the greater the availability of glucose will be, and consequently, the higher the LA production yield will be. The great challenge is the direct hydrolysis of lowcost biomass residues with good LA yields. The possibility of varying feedstock in the industrial process is strategic, because it decreases dependency on seasonality, harvests, and commodity prices that originate the residue. The yield that best evaluates process efficiency when the feedstock is in natura biomass or its residues is RG (Table 2), which indicates LA yield considering the amount of glucose available in the substrate.

The acidic hydrolysis of rice straw (40\% glucose in mass) yielded the best results among the evaluated biomass residues, with an RG of $51 \%$ ( $79 \%$ of theoretical yield) using $\mathrm{HCl}$, at $180{ }^{\circ} \mathrm{C}$ and $2 \mathrm{~h}$ of reaction. ${ }^{35}$ When using cane sugar bagasse ( $48 \%$ glucose in mass) at $150{ }^{\circ} \mathrm{C}$ and $8 \mathrm{~h}$, in the presence of $\mathrm{H}_{2} \mathrm{SO}_{4}$, an $\mathrm{RG}$ of $40.4 \%$ (62.7\% of the theoretical yield) was obtained. ${ }^{32}$ The direct hydrolysis of corn cob (60.7\% cellulose in mass) led to an RG of $48 \%$ (76\% of the theoretical yield), under the conditions of $200{ }^{\circ} \mathrm{C}$ and $4 \mathrm{~h}$ with $\mathrm{H}_{2} \mathrm{SO}_{4}{ }^{41}$ Paper sludge $\left(57.1 \%\right.$ cellulose in mass) treated with $\mathrm{HCl}$, at $200{ }^{\circ} \mathrm{C}, 30 \mathrm{bar}$, for $1 \mathrm{~h}$ led to the RG of $50 \%{ }^{49}$ ( $78 \%$ of the theoretical yield), and poplar sawdust (57.6\% cellulose) reached an RG of $45.8 \%{ }^{49}$ ( $71 \%$ of the theoretical yield, under equivalent reactional conditions: $200{ }^{\circ} \mathrm{C}$, 30 bar, and $1 \mathrm{~h}$ ).

Using Arundo donax in natura as raw material (40.7\% weight glucose), RG reached $56.1 \%{ }^{33}$ under conditions of $190{ }^{\circ} \mathrm{C}$ and 30 bar in $\mathrm{N}_{2}$, using a continuous reactor. However, this is a noble raw material, and is used in the market for other ends.

According to Table 2, good yields were obtained using biomass when compared to sugars and cellulose. It is verified that, when using cellulose, glucose and fructose as a substrate, the best values for RG were equal to $42.4 \%, 44.1 \%$, and $47.7 \%,{ }^{8,38,42}$ respectively. When using biomass residues, $\mathrm{RG}$ values were $40.4 \%$ for sugar cane bagasse, $51.5 \%$ for rice straw, $48.9 \%$ for corn cob, $50.0 \%$ for paper sludge, and $45.8 \%$ for poplar sawdust. ${ }^{32,35,41,49}$ Despite the separation difficulties inherent to the process containing impurities in the biomass residue, it seems economically advantageous to use these materials as feedstock for producing LA in a biorefinery.

The temperature range in the biomass residue processes was between $150{ }^{\circ} \mathrm{C}$ and $200{ }^{\circ} \mathrm{C}$, similar to the one used for cellulose and hexoses. Nevertheless, reaction times in the processes that used biomass residues as feedstock were longer. This problem can be diminished in case a pretreatment step that exposes cellulose is applied, reducing its crystallinity in order to favor hydrolysis. ${ }^{61}$

Animal-based biomass residues have also been studied as feedstock for producing LA. Chitin, a fishing industry residue, is the second most abundant polymer on the planet, and is present in crustaceans..$^{37,62}$ It consists of a polysaccharide formed by the 
Table 2. Comparison of different substrates and reaction conditions used in homogeneous LA production processes*

\begin{tabular}{|c|c|c|c|c|c|c|c|}
\hline Substrate & Reaction conditions & Catalyst & $\begin{array}{c}\mathrm{RS}^{\mathrm{a}} \\
\% \mathrm{~g} \mathrm{~g}_{-}{ }^{1} \\
\end{array}$ & $\begin{array}{c}\mathrm{TC}^{\mathrm{b}} \\
\% \mathrm{~g} \mathrm{~g}^{-1} \\
\end{array}$ & $\begin{array}{c}\mathrm{TG}^{\mathrm{c}} \\
\% \mathrm{~g} \mathrm{~g}^{-1} \\
\end{array}$ & $\begin{array}{c}\mathrm{RG}^{\mathrm{d}} \\
\% \mathrm{~g} \mathrm{~g}^{-1} \\
\end{array}$ & Reference \\
\hline Sugar cane bagasse & $150^{\circ} \mathrm{C}$ and $8 \mathrm{~h}$ & $\mathrm{H}_{2} \mathrm{SO}_{4}\left(0.55 \mathrm{~mol} \mathrm{~L}^{-1}\right)$ & 19.4 & 43.2 & 48.0 & 40.4 & 32 \\
\hline Arundo donax & $190^{\circ} \mathrm{C}$ and $30 \mathrm{bar}$ & $\mathrm{HCl}\left(0.55 \mathrm{~mol} \mathrm{~L}^{-1}\right)$ & 22.8 & 36.6 & 40.7 & 56.1 & 33 \\
\hline \multirow{3}{*}{ Rice straw } & $175^{\circ} \mathrm{C}$ and $75 \mathrm{~min}$ & $\mathrm{H}_{2} \mathrm{SO}_{4}(4 \%$ weight $)$ & 11.8 & 31.0 & 34.4 & 34.3 & 34 \\
\hline & $180^{\circ} \mathrm{C}$ and $2 \mathrm{~h}$ & $\mathrm{HCl}\left(2 \mathrm{~mol} \mathrm{~L}^{-1}\right)$ & 20.6 & - & 40.0 & 51.5 & 35 \\
\hline & $180^{\circ} \mathrm{C}$ and $3 \mathrm{~h}$ & $\mathrm{HCl}(0.4 \%$ weight $)$ & 10.0 & 36.4 & 40.4 & 29.0 & 36 \\
\hline \multirow{2}{*}{ Cellobiose } & $170^{\circ} \mathrm{C}$ and $30 \mathrm{~min}$ & $\mathrm{HCl}\left(2 \mathrm{~mol} \mathrm{~L}^{-1}\right)$ & 29.9 & (e) & (e) & 28.4 & \multirow{2}{*}{37} \\
\hline & $170{ }^{\circ} \mathrm{C}$ and $30 \mathrm{~min}$ & $\mathrm{H}_{2} \mathrm{SO}_{4}\left(2 \mathrm{~mol} \mathrm{~L}^{-1}\right)$ & 28.0 & (e) & (e) & 26.6 & \\
\hline \multirow{2}{*}{ Cellulose } & $170^{\circ} \mathrm{C}$ and $50 \mathrm{~min}$ & $\mathrm{HCl}\left(2 \mathrm{~mol} \mathrm{~L}^{-1}\right)$ & 31.0 & 100 & (f) & 27.9 & \multirow{2}{*}{37} \\
\hline & $170^{\circ} \mathrm{C}$ and $50 \mathrm{~min}$ & $\mathrm{H}_{2} \mathrm{SO}_{4}\left(2 \mathrm{~mol} \mathrm{~L}^{-1}\right)$ & 23.0 & 100 & (f) & 20.7 & \\
\hline \multirow{3}{*}{ Cellulose } & $160^{\circ} \mathrm{C}$ and $11 \mathrm{~min}$ & $\mathrm{HCl}\left(2.4 \mathrm{~mol} \mathrm{~L}^{-1}\right)$ & 39.1 & 100 & \multirow{3}{*}{ (f) } & 35.2 & \multirow{3}{*}{38} \\
\hline & $180^{\circ} \mathrm{C}$ and $11 \mathrm{~min}$ & $\mathrm{HCl}\left(1.6 \mathrm{~mol} \mathrm{~L}^{-1}\right)$ & 42.4 & 100 & & 38.2 & \\
\hline & $200^{\circ} \mathrm{C}$ and $11 \mathrm{~min}$ & $\mathrm{HCl}\left(0.8 \mathrm{~mol} \mathrm{~L}^{-1}\right)$ & 38.0 & 100 & & 34.2 & \\
\hline \multirow{3}{*}{ Cellulose } & $130^{\circ} \mathrm{C}$ and $8 \mathrm{~h}$ & $\mathrm{H}_{3} \mathrm{PW}_{12} \mathrm{O}_{40}\left(0.16 \mathrm{~mol} \mathrm{~L}^{-1}\right)$ & 11.3 & 100 & \multirow{3}{*}{ (f) } & 10.2 & \multirow{3}{*}{39} \\
\hline & $130^{\circ} \mathrm{C}$ and $8 \mathrm{~h}$ & $\mathrm{H}_{5} \mathrm{BW}_{12} \mathrm{O}_{40}\left(0.16 \mathrm{~mol} \mathrm{~L}^{-1}\right)$ & 17.2 & 100 & & 15.5 & \\
\hline & $130^{\circ} \mathrm{C}$ and $8 \mathrm{~h}$ & $\mathrm{H}_{4} \mathrm{SiW}_{12} \mathrm{O}_{40}\left(0.16 \mathrm{~mol} \mathrm{~L}^{-1}\right)$ & 18.6 & 100 & & 16.7 & \\
\hline $\begin{array}{l}\text { Eichhornia crassipes (aquatic } \\
\text { plant) }\end{array}$ & $175^{\circ} \mathrm{C}$ and $30 \mathrm{~min}$ & $\mathrm{H}_{2} \mathrm{SO}_{4}\left(1 \mathrm{~mol} \mathrm{~L}^{-1}\right)$ & 9.0 & - & 25.7 & 35.0 & 40 \\
\hline Corn cob & $200^{\circ} \mathrm{C}$ and $4 \mathrm{~h}$ & $\mathrm{H}_{2} \mathrm{SO}_{4}(3 \%$ weight $)$ & 33.0 & 60.7 & 67.4 & 48.9 & 41 \\
\hline \multirow{2}{*}{ Fructose } & $170^{\circ} \mathrm{C}$ and $30 \mathrm{~min}$ & $\mathrm{H}_{2} \mathrm{SO}_{4}\left(2 \mathrm{~mol} \mathrm{~L}^{-1}\right)$ & 27.8 & - & \multirow{2}{*}{100} & 27.8 & \multirow{2}{*}{37} \\
\hline & $170^{\circ} \mathrm{C}$ and $30 \mathrm{~min}$ & $\mathrm{HCl}\left(2 \mathrm{~mol} \mathrm{~L}^{-1}\right)$ & 31.8 & - & & 31.8 & \\
\hline Fructose & $140^{\circ} \mathrm{C}$ and $10 \mathrm{~min}$ & $\mathrm{H}_{2} \mathrm{SO}_{4}\left(1 \mathrm{~mol} \mathrm{~L}^{-1}\right)$ & 47.7 & - & 100 & 47.7 & 42 \\
\hline \multirow{2}{*}{ Glucose } & $170^{\circ} \mathrm{C}$ and $30 \mathrm{~min}$ & $\mathrm{HCl}\left(2 \mathrm{~mol} \mathrm{~L}^{-1}\right)$ & 31.4 & - & \multirow{2}{*}{100} & 31.4 & \multirow{2}{*}{37} \\
\hline & $170^{\circ} \mathrm{C}$ and $30 \mathrm{~min}$ & $\mathrm{H}_{2} \mathrm{SO}_{4}\left(2 \mathrm{~mol} \mathrm{~L}^{-1}\right)$ & 26.4 & - & & 26.4 & \\
\hline Glucose & $149^{\circ} \mathrm{C}$ and 41 bar & $\mathrm{HCl}\left(0.1 \mathrm{~mol} \mathrm{~L}^{-1}\right)$ & 44.1 & - & 100 & 44.1 & 8 \\
\hline Glucose & $181{ }^{\circ} \mathrm{C}$ and $44 \mathrm{~min}$ & $\mathrm{CH}_{3} \mathrm{SO}_{3} \mathrm{H}\left(0.35 \mathrm{~mol} \mathrm{~L}^{-1}\right)$ & 31.5 & - & \multirow{2}{*}{100} & 31.5 & 43 \\
\hline Glucose & $180^{\circ} \mathrm{C}$ and $60 \mathrm{~min}$ & $\mathrm{InCl}_{3}(2.5 \% \mathrm{~mol})$ & 29.0 & - & & 29.0 & 44 \\
\hline Glucose & $180^{\circ} \mathrm{C}$ and $15 \mathrm{~min}$ & $\mathrm{H}_{2} \mathrm{SO}_{4}\left(0.5 \mathrm{~mol} \mathrm{~L}^{-1}\right)$ & 42.1 & - & 100 & 42.1 & \multirow{2}{*}{45} \\
\hline Glucose & $180^{\circ} \mathrm{C}$ and $15 \mathrm{~min}$ & $\mathrm{CH}_{3} \mathrm{SO}_{3} \mathrm{H}\left(0.5 \mathrm{~mol} \mathrm{~L}^{-1}\right)$ & 40.7 & - & 100 & 40.7 & \\
\hline Glucose & $170{ }^{\circ} \mathrm{C}$ and $4.5 \mathrm{~h}$ & $\mathrm{H}_{3} \mathrm{PO}_{4}+\mathrm{CrCl}_{3}\left(0.02 \mathrm{~mol} \mathrm{~L}^{-1}\right)$ & 32.1 & - & 100 & 32.1 & \multirow{2}{*}{46} \\
\hline Glucose & $170^{\circ} \mathrm{C}$ and $4.5 \mathrm{~h}$ & $\mathrm{H}_{3} \mathrm{PO}_{4}+\mathrm{FeCl}_{3}\left(0.02 \mathrm{~mol} \mathrm{~L}^{-1}\right)$ & 19.2 & - & & 19.2 & \\
\hline Glucose & $170^{\circ} \mathrm{C}$ and $4.0 \mathrm{~h}$ & $\mathrm{H}_{3} \mathrm{PO}_{4}+\mathrm{CuCl}_{2}\left(0.02 \mathrm{~mol} \mathrm{~L}^{-1}\right)$ & 22.6 & - & 100 & 22.6 & 47 \\
\hline Glucosamine & $170^{\circ} \mathrm{C}$ and $10 \mathrm{~min}$ & $\mathrm{HCl}\left(2 \mathrm{~mol} \mathrm{~L}^{-1}\right)$ & 19.6 & - & - & - & \multirow{2}{*}{37} \\
\hline Glucosamine & $170{ }^{\circ} \mathrm{C}$ and $10 \mathrm{~min}$ & $\mathrm{H}_{2} \mathrm{SO}_{4}\left(2 \mathrm{~mol} \mathrm{~L}^{-1}\right)$ & 13.8 & - & - & - & \\
\hline Lemna minor (aquatic plant) & $180^{\circ} \mathrm{C}$ and $2.5 \mathrm{~h}$ & $\mathrm{HCl}(1.2 \%$ weight $)$ & 26.2 & - & 50.4 & 52.0 & 48 \\
\hline Paper sludge & $200^{\circ} \mathrm{C}, 30$ bar and $1 \mathrm{~h}$ & $\mathrm{H}_{2} \mathrm{SO}_{4}(8.3 \%$ weight $)$ & 15.4 & \multirow{2}{*}{57.1} & & 24.3 & 40 \\
\hline Paper sludge & $200^{\circ} \mathrm{C}, 30$ bar and $1 \mathrm{~h}$ & $\mathrm{HCl}$ (11.5\% weight) & 31.7 & & 63.4 & 50.0 & 49 \\
\hline Eucalyptus wood & $170^{\circ} \mathrm{C}$ and $5 \mathrm{~h}$ & $\mathrm{H}_{2} \mathrm{SO}_{4}\left(0.2 \mathrm{~mol} \mathrm{~L}^{-1}\right)$ & 15.9 & 48.9 & 54.3 & 29.3 & 50 \\
\hline Paper towel & $200^{\circ} \mathrm{C}$ and $1 \mathrm{~h}$ & $\mathrm{H}_{2} \mathrm{SO}_{4}\left(1 \mathrm{~mol} \mathrm{~L}^{-1}\right)$ & 13.9 & 78.1 & 868 & 16.0 & 51 \\
\hline Paper towel & $200{ }^{\circ} \mathrm{C}, 50$ bar and $5 \mathrm{~min}$ & $\mathrm{H}_{2} \mathrm{SO}_{4}\left(0.135 \mathrm{~mol} \mathrm{~L}^{-1}\right)$ & 9.7 & 18.1 & 86.8 & 11.1 & 52 \\
\hline Olive tree prunes & $200^{\circ} \mathrm{C}, 30$ bar and $1 \mathrm{~h}$ & $\mathrm{HCl}(11.5 \%$ weight $)$ & 18.6 & 39.4 & 43.8 & 42.5 & 49 \\
\hline Wood pulp & $188^{\circ} \mathrm{C}$ and $126 \mathrm{~min}$ & $\mathrm{H}_{2} \mathrm{SO}_{4}\left(0.193 \mathrm{~mol} \mathrm{~L}^{-1}\right)$ & 21.0 & 42.0 & 46.6 & 45.0 & 53 \\
\hline Chitin & $190^{\circ} \mathrm{C}$ and $30 \mathrm{~min}$ & $\mathrm{HCl}\left(2 \mathrm{~mol} \mathrm{~L}^{-1}\right)$ & 18.7 & - & - & - & 37 \\
\hline Chitin & $190^{\circ} \mathrm{C}$ and $30 \mathrm{~min}$ & $\mathrm{H}_{2} \mathrm{SO}_{4}\left(2 \mathrm{~mol} \mathrm{~L}^{-1}\right)$ & 21.6 & - & - & - & 31 \\
\hline Chitosan & $190^{\circ} \mathrm{C}$ and $20 \mathrm{~min}$ & $\mathrm{HCl}\left(2 \mathrm{~mol} \mathrm{~L}^{-1}\right)$ & 26.3 & - & - & - & 37 \\
\hline Chitosan & $190^{\circ} \mathrm{C}$ and $20 \mathrm{~min}$ & $\mathrm{H}_{2} \mathrm{SO}_{4}\left(2 \mathrm{~mol} \mathrm{~L}^{-1}\right)$ & 22.8 & - & - & - & 31 \\
\hline Chitosan & $200^{\circ} \mathrm{C}$ and $30 \mathrm{~min}$ & $\mathrm{CH}_{3} \mathrm{SO}_{3} \mathrm{H}\left(0.2 \mathrm{~mol} \mathrm{~L}^{-1}\right)$ & 28.2 & - & - & - & 54 \\
\hline Poplar sawdust & $200^{\circ} \mathrm{C}, 30$ bar and $1 \mathrm{~h}$ & $\mathrm{HCl}(11.5 \%$ weight $)$ & 29.3 & 57.6 & 64.0 & 45.8 & 49 \\
\hline
\end{tabular}

*The reactions occur in the liquid phase. In some cases, indicated in the table, the process occurs under $\mathrm{N}_{2}$ pressure. ${ }^{a} \mathrm{RS}$ : LA yield compared to substrate quan-


${ }^{\mathrm{d}} \mathrm{RG}$ : LA yield compared to the glucose quantity that can be obtained from the substrate; ${ }^{\mathrm{e}} 1 \mathrm{~mol}$ cellobiose $\left(342 \mathrm{~g} \mathrm{~mol}^{-1}\right)$ plus 1 mol of water resulting in $2 \mathrm{~mol}^{-1}$ of glucose $\left(180 \mathrm{~g} \mathrm{~mol}^{-1}\right) ;{ }^{\mathrm{f}} 1 \mathrm{~mol}^{\circ}$ of cellulose $\left(162 \mathrm{~g} \mathrm{~mol}^{-1}\right)$ plus $1 \mathrm{~mol}$ of water result in $1 \mathrm{~mol}$ of glucose $\left(180 \mathrm{~g} \mathrm{~mol}^{-1}\right)$. 
condensation of $\mathrm{N}$-acetylglucosamine with a molecular structure similar to lignocellulose. Chitosan is derived from chitin, after the removal of part of its acetyl groups, resulting in repeated structures of D-glucosamine glued together by glycosidic bonds. ${ }^{62-64}$ In 2018 , the global production of crustaceans was 9.4 million tons per year, ${ }^{65}$ which resulted in a significant quantity of residue,,${ }^{54}$ that can be used for obtaining LA in a biorefinery.

The theoretical yield is $57.1 \%\left(\mathrm{~g} \mathrm{~g}^{-1}\right)$, considering one mole of chitin $\left(203 \mathrm{~g} \mathrm{~mol}^{-1}\right)$ results in one mol of LA. Nevertheless, RS in the obtainment of LA from chitin (21.6\%), ${ }^{37}$ chitosan $(28,2 \%),{ }^{54}$ and glucosamine $(19.6 \%)^{37}$ are still low when compared to plant-based residues, needing further studies for their use as a substrate.

\section{Processes that use heterogeneous catalysis}

LA synthesis from heterogeneous catalysts uses solids with strong acid sites that allow the conversion of glucose. ${ }^{29}$ Heterogeneous processes can be conducted in cheaper reactors, and the catalyst can be used for longer without the need for its separation from the end product, as happens in homogeneous systems..$^{19,30,31}$ Therefore, the use of a solid acid catalyst is an alternative for industrial applications in LA synthesis from biomass, in an attempt to reduce production steps, and consequently, production costs. ${ }^{66,67}$ Table 3 displays a comparison of LA production processes employing heterogeneous catalysts under several LA synthesis operational conditions. ${ }^{11,39,68-91}$

From the analyses of publications presented in Table 3, it can be verified that the used temperatures varied between $120^{\circ} \mathrm{C}$ and $230^{\circ} \mathrm{C}$, equivalent to those used in homogeneous processes (Table 2). In batch reactors, in order to reach comparable yields, much longer reaction times in heterogeneous processes were needed..$^{27}$ Longer residence times led to an increase in reactor volume, leading to higher costs.

Cellulose hydrolysis yields depend on the strength and type of acid (Brønsted or Lewis) present in the catalyst. Among the evaluated catalysts presented in Table 3, heteropolyacids can be highlighted, which have been used in the conversion of cellulose into LA. When the substrate was commercial cellulose, the best $\mathrm{RS}$ value was $65.6 \%$ under the conditions of $130{ }^{\circ} \mathrm{C}$ and $8 \mathrm{~h}$ in the presence of the $\mathrm{H}_{\mathrm{n}} \mathrm{PW}_{11} \mathrm{TiO}_{40}$ catalyst, ${ }^{39}$ a value much superior to the best $\mathrm{RS}$ of $42.4 \%$ obtained with the homogeneous catalyst. ${ }^{38}$ For the temperatureresponsive catalyst $\left(\mathrm{ChH}_{4} \mathrm{PWTi}\right)$ an $\mathrm{RS}$ of $76.1 \%$ was obtained using cellulose as a substrate, and hydrochloric acid, though there was a higher reaction time requirement of circa 8 h. ${ }^{39}$ The catalyst was recycled 12 times with no significant activity loss. The authors report that strong Brønsted acid sites are responsible for the conversion of cellulose, and the presence of Lewis acid sites improves selectivity to LA. ${ }^{39}$ Despite the reported yield was based on mass (mass of LA/initial mass of cellulose), the value is, probably, molar yield, indicating the theoretical value of the yield of the cellulose transformation in LA, as confirmed in previous citations for the work..$^{92-94}$ In any case, the theoretical yield obtained of $76.1 \%$ is an outstanding value, surpassing the value of $70.0 \%$ obtained in the industrial production of LA. ${ }^{9}$

Emphasis can also be given to the innovative process that displayed a molar yield of $91.0 \%$ in LA ( $\mathrm{mol}$ of carbon in LA)/(mol of carbon in initial cellulose), using cellulose as feedstock while operating at $200^{\circ} \mathrm{C}$ for $6 \mathrm{~h}$ and 60 bar hydrogen pressure. ${ }^{71}$ This yield corresponds to an RS of $78.2 \%$, and the value surpasses the maximum possible theoretical yield, which would be $83.3 \%$ (6 mol of carbon in cellulose resulting in $5 \mathrm{~mol}$ of carbon in LA).

Considering that glucose can be easily isomerized to and coexist with fructose, and both can suffer dehydration, glucose and fructose can directly lead to 5-HMF and then to LA and FA. ${ }^{29,71,95} \mathrm{~A}$ mechanism, hinged on a nickel-based mesoporous ETS-10 catalyst containing only Lewis strong acid sites, proposes that oxygen from the glucose hydroxyl or fructose group adsorbs onto these Lewis sites, producing fructofuranose, ${ }^{94}$ which isomerizes into $\mathrm{HMF}$, later forming LA (Figure 6). ${ }^{71}$

Most publications shown in Table 3 used sugars or cellulose as a substrate, which indicates difficulty in performing the hydrolysis of in natura biomass in single-step heterogeneous processes. Glucose and fructose were used to obtain LA with an RS value of $50.3 \%$ at $200{ }^{\circ} \mathrm{C}$ and $2 \mathrm{~h}$, which is superior to the yield of homogeneous catalysis (RS: $44.1 \%$ for glucose ${ }^{8}$ and $47.7 \%$ for fructose ${ }^{42}$ ), employing graphene sulfonated oxide as a catalyst. ${ }^{79}$

The use of biomass residues resulted in satisfactory results, e.g. corn cob, which under the conditions of $193{ }^{\circ} \mathrm{C}$ and $17 \mathrm{~min}$, in the presence of $\mathrm{SnCl}_{4}$ catalyst, was hydrolyzed, obtaining an RS of $17.8 \%$ and an RG of $49 \%$ (76\% of theoretical yield). ${ }^{74}$ Corn straw was used under the conditions of $190^{\circ} \mathrm{C}$ and $80 \mathrm{~min}$, using SAPO- 18 as a catalyst, obtaining an RG of $45.2 \%{ }^{86} \mathrm{LA}$ was synthesized from bamboo residue at $140{ }^{\circ} \mathrm{C}$ and $4 \mathrm{~h}$ on mordenite, obtaining an RS of $13.5 \%$ and an RG of $39.2 \% .{ }^{89}$ Glucose was used as a substrate, obtaining an RS of $50.3 \%$ ( $78 \%$ of theoretical yield) at $200{ }^{\circ} \mathrm{C}$ and $2 \mathrm{~h}$ in the presence of graphene sulfonated oxide..$^{79}$ This value is superior to corn straw and bamboo residue $\mathrm{RG}^{86,89}$ though, in comparison to corn cob, the yield was somewhat higher. Besides, corn cob was hydrolyzed at a lower temperature and shorter reaction times, ${ }^{74}$ which would turn the process from this residue more advantageous because of reduced operational costs.

Heterogeneous catalysis has the advantage of allowing the reuse of the catalyst, reducing its replacement and separation costs. The regeneration of catalysts in the synthesis of LA to reactivate the catalytic sites, gaining efficiency, can be done by different processes. Calcination, for example, at temperatures around $500{ }^{\circ} \mathrm{C}$ is efficient for removing organic deposits on the surface of the catalyst, while an acid immersion treatment can be used to recover hydrogen ions through an ion exchange process with metal cations. ${ }^{29}$ Other procedures involve washing the catalyst with organic solvents or with $\mathrm{H}_{2} \mathrm{O}_{2}$ to regenerate catalyst active sites. ${ }^{29,51}$

A problem of LA synthesis in heterogeneous processes is humin deposition on the catalyst surface, covering active sites, and provoking its deactivation. ${ }^{32,38}$ In addition, the high acidity of Lewis sites increases the conversion of glucose into humins. ${ }^{29}$ Currently, LA industrial production processes use homogeneous catalysts. However, technical and economic feasibility studies of heterogeneous processes are important because this path may aggregate flexibility to the biorefinery with another alternative.

Processes that use acid catalysis and ionic liquids

Ionic liquids (IL) have been thoroughly studied as solvents,

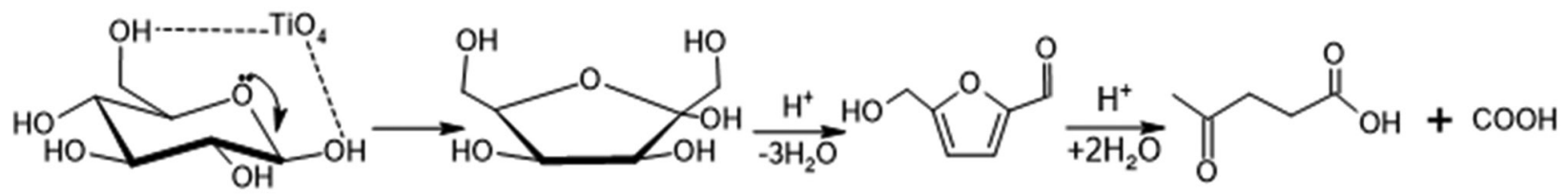


Table 3. Comparison of different substrates and reaction conditions used in heterogeneous catalysis for producing LA*

\begin{tabular}{|c|c|c|c|c|c|c|c|}
\hline Substrate & Reaction conditions & Catalyst & $\begin{array}{l}\mathrm{RS}^{\mathrm{a}} \\
\% \mathrm{~g} \mathrm{~g}^{-1}\end{array}$ & $\begin{array}{l}\mathrm{TC}^{\mathrm{b}} \\
\% \mathrm{~g} \mathrm{~g}^{-1}\end{array}$ & $\begin{array}{l}\mathrm{TG}^{\mathrm{c}} \\
\% \mathrm{~g} \mathrm{~g}^{-1}\end{array}$ & $\begin{array}{l}\mathrm{RG}^{\mathrm{d}} \\
\% \mathrm{~g} \mathrm{~g}^{-1}\end{array}$ & Reference \\
\hline Cellulose & $180^{\circ} \mathrm{C}$ and $3 \mathrm{~h}$ & $\mathrm{ZrO}_{2}$ & 38.6 & 100 & (e) & 34.7 & 68 \\
\hline Cellulose & $200^{\circ} \mathrm{C}$ and $3 \mathrm{~h}$ & $\mathrm{CrCl}_{3}$ & 48.0 & 100 & (e) & 43.2 & 69 \\
\hline Cellulose & $170^{\circ} \mathrm{C}$ and $10 \mathrm{~h}$ & $\begin{array}{l}\text { Chloromethyl polystyrene } \\
\text { sulfonated resin }\end{array}$ & 46.9 & 100 & (e) & 42.2 & 70 \\
\hline Cellulose & $200^{\circ} \mathrm{C}, 60$ bar and $6 \mathrm{~h}$ & $\begin{array}{c}\text { Zeolite } \\
\text { Ni-HMETS-10 }\end{array}$ & 78.2 & 100 & (e) & 70.4 & 71 \\
\hline Cellulose & $180^{\circ} \mathrm{C}$ and $7 \mathrm{~h}$ & Nafion® NR50. with $\mathrm{H}_{2} \mathrm{SO}_{4}$ & 40.4 & 100 & (e) & 36.4 & 72 \\
\hline Cellulose & $180^{\circ} \mathrm{C}$ and $2 \mathrm{~h}$ & Amberlyst 15 and $\mathrm{Al}_{2}\left(\mathrm{SO}_{4}\right)_{3}$ & 52.5 & 100 & (e) & 47.2 & 73 \\
\hline Cellulose & $130^{\circ} \mathrm{C}$ and $8 \mathrm{~h}$ & $\mathrm{H}_{\mathrm{n}} \mathrm{PW}_{11} \mathrm{TiO}_{40}$ & 65.6 & 100 & (e) & 59.0 & \multirow{8}{*}{39} \\
\hline Cellulose & $130^{\circ} \mathrm{C}$ and $8 \mathrm{~h}$ & $\mathrm{H}_{\mathrm{n}} \mathrm{PW}_{11} \mathrm{CuO}_{39}$ & 54.7 & 100 & (e) & 49.2 & \\
\hline Cellulose & $130^{\circ} \mathrm{C}$ and $8 \mathrm{~h}$ & $\mathrm{H}_{\mathrm{n}} \mathrm{PW}_{11} \mathrm{SnO}_{39}$ & 47.1 & 100 & (e) & 42.4 & \\
\hline Cellulose & $130^{\circ} \mathrm{C}$ and $8 \mathrm{~h}$ & $\mathrm{H}_{\mathrm{n}} \mathrm{PW}_{11} \mathrm{ZrO}_{40}$ & 43.8 & 100 & (e) & 39.4 & \\
\hline Cellulose & $130^{\circ} \mathrm{C}$ and $8 \mathrm{~h}$ & $\mathrm{H}_{\mathrm{n}} \mathrm{PW}_{11} \mathrm{ZnO}_{39}$ & 31.6 & 100 & (e) & 28.4 & \\
\hline Cellulose & $130^{\circ} \mathrm{C}$ and $8 \mathrm{~h}$ & $\mathrm{H}_{\mathrm{n}} \mathrm{PW}_{11} \mathrm{FeO}_{39}$ & 29.9 & 100 & (e) & 26.9 & \\
\hline Cellulose & $130^{\circ} \mathrm{C}$ and $8 \mathrm{~h}$ & $\mathrm{H}_{\mathrm{n}} \mathrm{PW}_{11} \mathrm{CrO}_{39}$ & 28.5 & 100 & (e) & 25.7 & \\
\hline Cellulose & $130^{\circ} \mathrm{C}$ and $8 \mathrm{~h}$ & $\mathrm{ChH}_{4} \mathrm{PWTi}$ & 76.1 & 100 & (e) & 68.5 & \\
\hline Corn cob & $193{ }^{\circ} \mathrm{C}$ and $17 \mathrm{~min}$ & $\mathrm{SnCl}_{4}$ & 17.8 & 32.6 & 36.2 & 49.0 & 74 \\
\hline Fructose & $120^{\circ} \mathrm{C}$ and $3 \mathrm{~h}$ & $\begin{array}{l}\text { Sulfonated Styrene-divinylben- } \\
\text { zene porous resin }\end{array}$ & 31.5 & - & 100 & 31.5 & \multirow[t]{2}{*}{75} \\
\hline Fructose & $120^{\circ} \mathrm{C}$ and $3 \mathrm{~h}$ & $\mathrm{Nb}_{2} \mathrm{O}_{5}$ & 0.8 & - & 100 & 0.8 & \\
\hline Fructose & $160^{\circ} \mathrm{C}$ and $1 \mathrm{~h}$ & Graphene sulfonated oxide & 39.4 & - & 100 & 39.4 & 76 \\
\hline Fructose & $180^{\circ} \mathrm{C}, 10 \mathrm{bar}$ and $5 \mathrm{~h}$ & SBA-1 & 19.3 & - & 100 & 19.3 & 77 \\
\hline Fructose & $120^{\circ} \mathrm{C}, 7-34 \mathrm{bar}$ and $24 \mathrm{~h}$ & Polystyrene sulfonates resin & 46.4 & - & 100 & 46.4 & 78 \\
\hline Fructose & $200^{\circ} \mathrm{C}$ and $2 \mathrm{~h}$ & Graphene sulfonated oxide & 47.7 & - & 100 & 47.7 & \multirow{3}{*}{79} \\
\hline Glucose & $200^{\circ} \mathrm{C}$ and $2 \mathrm{~h}$ & Graphene oxide & 8.4 & - & 100 & 8.4 & \\
\hline Glucose & $200^{\circ} \mathrm{C}$ and $2 \mathrm{~h}$ & Graphene sulfonated oxide & 50.3 & - & 100 & 50.3 & \\
\hline Glucose & $170^{\circ} \mathrm{C}$ and $10 \mathrm{~h}$ & $\begin{array}{l}\text { Chloromethyl polystyrene } \\
\text { sulfonated resin }\end{array}$ & 28.5 & - & 100 & 28.5 & 70 \\
\hline Glucose & $130^{\circ} \mathrm{C}$ and $30 \mathrm{~min}$ & $\begin{array}{c}\left(\mathrm{C}_{6} \mathrm{H}_{15} \mathrm{O}_{2} \mathrm{~N}_{2}\right)_{3}-\mathrm{H}_{\mathrm{x}} \mathrm{PW}_{12} \mathrm{O}_{40} \\
\text { nanoparticles }\end{array}$ & 33.9 & - & 100 & 33.9 & 80 \\
\hline Glucose & $180^{\circ} \mathrm{C}$ and $3 \mathrm{~h}$ & $\mathrm{Cr} / \mathrm{HZSM}-5$ & 41.5 & - & 100 & 41.5 & 81 \\
\hline Glucose & $180^{\circ} \mathrm{C}$ and $3 \mathrm{~h}$ & Niobium oxides & 41.5 & - & 100 & 41.5 & 82 \\
\hline Glucose & $180^{\circ} \mathrm{C}$ and $4 \mathrm{~h}$ & $\mathrm{Fe} / \mathrm{HY}$ Zeolite & 42.5 & - & 100 & 42.5 & 83 \\
\hline Glucosamine & $200^{\circ} \mathrm{C}$ and $20 \mathrm{~min}$ & $\mathrm{ZrOCl}_{2}$ & 13.8 & - & - & - & 84 \\
\hline Levogluco-senone & $180^{\circ} \mathrm{C}$ and $2 \mathrm{~h}$ & Amberlyst 70 & 79.8 & - & - & - & 85 \\
\hline Mannose & $120^{\circ} \mathrm{C}$ and $3 \mathrm{~h}$ & $\mathrm{Nb}_{2} \mathrm{O}_{5}$ & 0.1 & - & - & - & 75 \\
\hline Corn straw & $190^{\circ} \mathrm{C}$ and $80 \mathrm{~min}$ & SAPO-18 Zeolite & - & - & - & 45.2 & 86 \\
\hline Corn straw & $230^{\circ} \mathrm{C}$ and $10 \mathrm{~min}$ & $\mathrm{FeCl}_{3}$ & 14.5 & 41.5 & 46.1 & 31.4 & 87 \\
\hline Chitin & $200^{\circ} \mathrm{C}$ and $30 \mathrm{~min}$ & $\mathrm{SnCl}_{4} .5 \mathrm{H}_{2} \mathrm{O}$ & 23.9 & - & - & - & 88 \\
\hline Bamboo residue & $140^{\circ} \mathrm{C}$ and $4 \mathrm{~h}$ & Mordenite Zeolite & 13.5 & 31.0 & 34.4 & 39.3 & 89 \\
\hline Bamboo residue & $200^{\circ} \mathrm{C}$ and $2 \mathrm{~h}$ & $\mathrm{SnCl}_{4}$ & 7.2 & 41.0 & 45.5 & 15.9 & 90 \\
\hline Corn cob hydrolyzes residue & $170{ }^{\circ} \mathrm{C}$ and $40 \mathrm{~min}$ & $\mathrm{FeCl}_{3}$ & 25.8 & 61.0 & 67.8 & 38.0 & 91 \\
\hline Xylose residue & $180^{\circ} \mathrm{C}$ and $2 \mathrm{~h}$ & $\mathrm{FeCl}_{3}$ & 29.7 & 61.0 & 67.8 & 43.8 & 11 \\
\hline Sucrose & $120^{\circ} \mathrm{C}$ and $3 \mathrm{~h}$ & $\begin{array}{c}\text { Sulfonated Styrene-divinylben- } \\
\text { zene porous resin }\end{array}$ & 5.8 & - & (f) & 5.8 & 75 \\
\hline Sucrose & $170{ }^{\circ} \mathrm{C}$ and $10 \mathrm{~h}$ & $\begin{array}{c}\text { Chloromethyl polystyrene } \\
\text { sulfonated resin }\end{array}$ & 16.5 & - & (f) & 17.3 & 70 \\
\hline
\end{tabular}

*aRS: LA yield compared to substrate amount; ${ }^{\text {TC: }}$ Substrate cellulose content; ${ }^{\mathrm{c}} \mathrm{TG}$ : Glucose or fructose content that can be obtained from the substrate based on the amount of cellulose that can be hydrolyzed; ${ }^{\mathrm{d}} \mathrm{RG}$ :LA yield compared to the amount of glucose that can be obtained from the substrate; ${ }^{\mathrm{e}} 1 \mathrm{~mol}$ cellulose $\left(162 \mathrm{~g} \mathrm{~mol}^{-1}\right)$ plus $1 \mathrm{~mol}$ water result in 1 mol glucose $\left(180 \mathrm{~g} \mathrm{~mol}^{-1}\right) ;{ }^{\mathrm{f}} 1 \mathrm{~mol}$ sucrose $(342 \mathrm{~g})$ results in 2 mol glucose $(360 \mathrm{~g})$. 
reactants or catalysts in various reactions due to their low vapor pressure, thermochemical stability, and versatility of their physical-chemical properties. ${ }^{96-99}$ These properties can be adjusted by the combinations of cations and anions, allowing for the use of these substances in several chemical processes. ${ }^{100,101}$ ILs are formed, for example, by cations derived from alkyl imidazoles, pyrrolidines, quaternary alkyl amines, and alkyl phosphines, and anions, derived from halides, alkyl sulfates, fluorinated hydrocarbons, carboxylic acids, and aminoacids. ${ }^{100}$ IL reactions can be homogeneous, heterogeneous with two-phase liquids, and solid-liquid heterogeneous with the IL immobilized in support. ${ }^{99}$ Despite the immobilized IL being preferable for it facilitates the separation and recovery of the catalyst, it is a limited option because of low activity and selectivity. ${ }^{102}$

Acidity is a fundamental characteristic for ionic liquids to be used in LA obtainment processes. The acidity, intrinsic to some ILs, promotes the weakening of glycosidic cellulose bonds, easing its hydrolysis. ${ }^{15,101}$ Table 4 shows a comparison of LA synthesis processes employing ionic liquids under several reaction conditions. ${ }^{1,96,103-114}$

Most reactions presented in Table 4 were conducted at temperatures between 100 and $200^{\circ} \mathrm{C}$, with the addition of ILs, which increase system acidity. ILs containing cations and hydroxyl groups form strong hydrogen bonds with glucose, and present better results at biomass conversion. The IL hydrogen bond weakens $\mathrm{C}-\mathrm{O}$ bonds of glucose, decreasing the activation energy at the dehydration step. ${ }^{26}$ Reactions in IL-containing media are slower, and most authors have worked with long reaction times, leading to an increase in operational costs when scaling up.

ILs containing an imidazolium cation $\left(\mathrm{C}_{3} \mathrm{H}_{3} \mathrm{~N}_{2}{ }^{+}\right)$is present in most publications herein evaluated, due to their physical-chemical characteristics and malleability: it is non-flammable, possesses high thermal stability and low volatility. ${ }^{115}$ Cellulose hydrolysis in $\left[\mathrm{C}_{3} \mathrm{SO}_{3} \mathrm{HMIm}\right] \mathrm{HSO}_{4}$ containing media for $5 \mathrm{~h}$ and $170{ }^{\circ} \mathrm{C}$ led to an $\mathrm{RG}$ of $55.2 \%,{ }^{108}$ and rice straw hydrolysis in $\left[\mathrm{C}_{3} \mathrm{SO}_{3} \mathrm{HMIm}\right] \mathrm{Cl}$ solution at $180{ }^{\circ} \mathrm{C}$ and $1.5 \mathrm{~h}$ obtained an RG of $62.2 \% .^{106}$ The hydrolysis of fruit bunch (TC of $41.0 \%$ ) under the conditions of $177^{\circ} \mathrm{C}$ and $140 \mathrm{~min}$, in the presence of [EMIm] [Cl] ionic liquid, resulted in an $\mathrm{RG}$ of $43.9 \%$ while commercial cellulose under the same reaction conditions presented an RG of $41.4 \%{ }^{103}$ The reaction with Crotalaria juncea fiber (TC of 75.6\%), in a system containing [BMIm][Cl], and palm (TC of $45.2 \%$ ), in a system with [SMIm] $\left[\mathrm{FeCl}_{4}\right]$, resulted in an RS of $53.5 \%$ and $49.4 \%$, respectively. Though yields are close, palm leaves hydrolysis used lower temperatures and longer residence times..$^{96,109}$

It can be verified that there are several publications aiming at LA production in IL media, although its commercial use is currently limited due to economic, scientific, technical and environmental factors. ${ }^{15}$ The high cost of ionic liquids is a barrier when compared to other solvents and catalysts. During processing, several stages of purification, with a high consumption of energy and chemicals, are needed. ${ }^{116}$ The processes downstream to the reactor are of great importance to LA recovery and IL separation for reuse. In washing, with water or organic solvent, there is the formation of three phases:

Table 4. Comparison of LA synthesis processes employing ionic liquids under several reaction conditions*

\begin{tabular}{|c|c|c|c|c|c|c|c|}
\hline Substrate & Reaction conditions & Ionic liquid & $\begin{array}{l}\mathrm{RS}^{\mathrm{a}} \\
\% \mathrm{~g} \mathrm{~g}^{-1}\end{array}$ & $\begin{array}{c}\mathrm{TC}^{\mathrm{b}} \\
\% \mathrm{~g} \mathrm{~g}^{-1}\end{array}$ & $\begin{array}{c}\mathrm{TG}^{\mathrm{c}} \\
\% \mathrm{~g} \mathrm{~g}^{-1}\end{array}$ & $\begin{array}{l}\mathrm{RG}^{\mathrm{d}} \\
\% \mathrm{~g} \mathrm{~g}^{-1}\end{array}$ & Reference \\
\hline Fruit bunch & $177^{\circ} \mathrm{C}$ and $140 \mathrm{~min}$ & {$[\mathrm{EMIm}][\mathrm{Cl}]$} & 20.0 & 41.0 & 45.6 & 43.9 & 103 \\
\hline Palm mesocarp & $160^{\circ} \mathrm{C}$ and $5 \mathrm{~h}$ & {$[\mathrm{HMIm}]\left[\mathrm{HSO}_{4}\right]$} & 8.9 & 33.2 & 36.9 & 24.1 & 104 \\
\hline Hemp & $120^{\circ} \mathrm{C}$ and $12 \mathrm{~h}$ & {$\left[\mathrm{C}_{2} \mathrm{C}_{1} \operatorname{Im}\right] \mathrm{Cl}$} & 11.5 & 34.0 & 37.8 & 30.4 & 105 \\
\hline Rice straw & $180^{\circ} \mathrm{C}$ and $1.5 \mathrm{~h}$ & {$\left[\mathrm{C}_{3} \mathrm{SO}_{3} \mathrm{HMIm}\right] \mathrm{Cl}$} & 21.6 & - & $34.7^{\mathrm{e}}$ & 62.2 & 106 \\
\hline Cellulose & $170^{\circ} \mathrm{C}$ and $30 \mathrm{~min}$ & {$\left[\mathrm{C}_{3} \mathrm{SO}_{3} \mathrm{HMIm}\right] \mathrm{HSO}_{4}$} & 39.4 & 100 & (f) & 35.4 & 107 \\
\hline Cellulose & $177^{\circ} \mathrm{C}$ and $140 \mathrm{~min}$ & {$[\mathrm{EMIm}][\mathrm{Cl}]$} & 46.0 & 100 & (f) & 41.4 & 103 \\
\hline Cellulose & $100{ }^{\circ} \mathrm{C}$ and $3 \mathrm{~h}$ & {$\left[\mathrm{~B}(\mathrm{MIm})_{2}\right]\left[2\left(\mathrm{HSO}_{4}\right)\left(\mathrm{H}_{2} \mathrm{SO}_{4}\right)_{2}\right]$} & 36.3 & 100 & (f) & 32.7 & 1 \\
\hline Cellulose & $170^{\circ} \mathrm{C}$ and $5 \mathrm{~h}$ & {$\left[\mathrm{C}_{3} \mathrm{SO}_{3} \mathrm{HMIm}\right] 1-\mathrm{NS}$} & 38.5 & 100 & (f) & 34.7 & \multirow{6}{*}{108} \\
\hline Cellulose & $170{ }^{\circ} \mathrm{C}$ and $5 \mathrm{~h}$ & {$\left[\mathrm{C}_{3} \mathrm{SO}_{3} \mathrm{HMIm}\right] \mathrm{CH}_{3} \mathrm{SO}_{3}$} & 38.6 & 100 & (f) & 34.7 & \\
\hline Cellulose & $170^{\circ} \mathrm{C}$ and $5 \mathrm{~h}$ & {$\left[\mathrm{C}_{3} \mathrm{SO}_{3} \mathrm{HPPh}_{3}\right] \mathrm{HSO}_{4}$} & 39.5 & 100 & (f) & 35.6 & \\
\hline Cellulose & $170^{\circ} \mathrm{C}$ and $5 \mathrm{~h}$ & {$\left[\mathrm{C}_{3} \mathrm{SO}_{3} \mathrm{HMIm} \mathrm{H}_{2} \mathrm{PO}_{4}\right.$} & 12.0 & 100 & (f) & 10.8 & \\
\hline Cellulose & $170{ }^{\circ} \mathrm{C}$ and $5 \mathrm{~h}$ & {$\left[\mathrm{C}_{3} \mathrm{SO}_{3} \mathrm{HMIm}\right] \mathrm{HSO}_{4}$} & 61.7 & 100 & (f) & 55.5 & \\
\hline Cellulose & $170{ }^{\circ} \mathrm{C}$ and $5 \mathrm{~h}$ & {$\left[\mathrm{C}_{3} \mathrm{SO}_{3} \mathrm{HPy}\right] \mathrm{HSO}_{4}$} & 40.7 & 100 & (f) & 36.7 & \\
\hline Crotalaria juncea fibers & $200^{\circ} \mathrm{C}$ and $46 \mathrm{~min}$ & {$[\mathrm{BMIm}][\mathrm{Cl}]$} & 44.9 & 75.6 & 84.0 & 53.5 & 109 \\
\hline Palm fibers & $160{ }^{\circ} \mathrm{C}$ and $5 \mathrm{~h}$ & {$[\mathrm{HMIm}]\left[\mathrm{HSO}_{4}\right]$} & 10.3 & 33.2 & 36.9 & 27.9 & 104 \\
\hline Palm leaves & $155^{\circ} \mathrm{C}$ and $222 \mathrm{~min}$ & {$[\mathrm{SMIm}]\left[\mathrm{FeCl}_{4}\right]$} & 24.8 & 45.2 & 50.2 & 49.4 & 96 \\
\hline Fructose & $95^{\circ} \mathrm{C}$ and $1 \mathrm{~h}$ & {$\left[\mathrm{BMIm}-\mathrm{SO}_{3} \mathrm{H}\right] \mathrm{HSO}_{4}$} & 45.1 & - & 100 & 45.1 & 110 \\
\hline Glucose & $150^{\circ} \mathrm{C}$ and $4 \mathrm{~h}$ & {$[\mathrm{BMIM}]\left[\mathrm{FeCl}_{4}\right]$} & 22.4 & - & 100 & 22.4 & 111 \\
\hline Glucose & $150^{\circ} \mathrm{C}$ and $4 \mathrm{~h}$ & {$[\mathrm{SMIm}][\mathrm{Cl}]$} & 25.8 & - & 100 & 25.8 & 111 \\
\hline Glucose & $155^{\circ} \mathrm{C}$ and $1.5 \mathrm{~h}$ & {$\left[\mathrm{IL}-\mathrm{SO}_{3} \mathrm{H}\right][\mathrm{Cl}]$ and $\mathrm{NiSO}_{4} \cdot 6 \mathrm{H}_{2} \mathrm{O}$} & 36.3 & - & 100 & 36.3 & 112 \\
\hline Hibiscus cannabinus & $177^{\circ} \mathrm{C}$ and $140 \mathrm{~min}$ & {$[\mathrm{EMIm}][\mathrm{Cl}]$} & 17.0 & 32.0 & 35.6 & 47.8 & 106 \\
\hline Chitin & $180^{\circ} \mathrm{C}$ and $2 \mathrm{~h}$ & {$\left[\mathrm{C}_{3} \mathrm{SO}_{3} \mathrm{HMIm}\right] \mathrm{HSO}_{4}$} & 38.3 & - & - & - & 113 \\
\hline Chitosan & $170^{\circ} \mathrm{C}$ and $5 \mathrm{~h}$ & {$\left[\mathrm{C}_{3} \mathrm{SO}_{3} \mathrm{HMIm}\right] \mathrm{HSO}_{4}$} & 41.5 & - & - & - & 114 \\
\hline Bamboo residue & $110^{\circ} \mathrm{C}$ and $1 \mathrm{~h}$ & $\mathrm{~B}(\mathrm{MIm})_{2}\left[\left(2 \mathrm{HSO}_{4}\right)\left(\mathrm{H}_{2} \mathrm{SO}_{4}\right)_{4}\right]$ & 13.7 & 40.3 & 44.7 & 30.6 & 102 \\
\hline
\end{tabular}

*aRS: LA yield according to substrate quantity; ${ }^{\mathrm{b} T C}$ : Substrate cellulose content; ${ }^{\mathrm{c} T G}$ : Glucose or fructose content that can be obtained from the substrate based on the cellulose amount that can be hydrolyzed; ${ }^{\mathrm{d}} \mathrm{RG}$ : LA yield according to the amount of glucose that can be obtained from the substrate; ${ }^{\mathrm{e}}$ Total hexose content in biomass ${ }^{\mathrm{f}} 1 \mathrm{~mol}$ cellulose $\left(162 \mathrm{~g} \mathrm{~mol}^{-1}\right)$ plus one mol water result in one mol glucose $\left(180 \mathrm{~g} \mathrm{~mol}^{-1}\right)$. 




Figure 7. Levulinic acid production process (Segetis Inc) ${ }^{55}$

the organic, the intermediary (aqueous), and the bottom (humins and non-reacted solids). Isolating LA involves separating the bottom phase and then extracting LA and the IL from the reactional media, using an appropriate solvent. For the IL has more affinity to water, it stays in the aqueous phase, while LA will preferably be present in the organic phase. Phases are then separated, and the IL returns to the reactor after purification.

It is expected that LA synthesis in a one-pot IL process becomes feasible with the IL acting in the pretreatment and in substrate hydrolysis. ${ }^{61} \mathrm{~A}$ worsening factor for in natura biomass processing is that IL purity, stability, and humidity are significantly altered, leading to extra recovery costs. Every step and solvent use must be analyzed to avoid the formation of liquid waste, which would turn the process unattractive when it comes to environmental protection, which is considered the main reason for the use of biomass in the obtainment of sustainable products.

\section{Industrial processes for obtaining levulinic acid}

Biofine and Segetis Inc. are the most widely known LA production processes. Biofine was developed by Stephen W. Fitzpatrick in 1997, and was one of the first means of producing and commercializing LA, having biomass as feedstock. ${ }^{23}$ Initially, the mixing of sulfuric or hydrochloric acid occurs (up to $5 \%$ weight of the mixture) with biomass, promoting biomass hydrolysis, producing glucose. The mixture is then pumped to a tube reactor with steam injection in order to keep the mixture heated between 215 and $230^{\circ} \mathrm{C}$ at 31 bar and residence time of $12 \mathrm{~s}$. In this first reactor, total degradation of biomass into glucose occurs, and some glucose that may already be present in the mixture is converted into HMF. After the tube reactor, the mixture heads to a CSTR (continuous stirred-tank reactor) which must be at a temperature between 210 and $220^{\circ} \mathrm{C}$, pressure around 15 bar with a residence time between 20 e 30 min, converting HMF into LA having furfural, residual lignin, and humins as byproducts. ${ }^{9,23}$

The Biofine process presents an average RG of $38.6 \%$ (60\% of theoretical yield), and can reach an RG of up to $45.1 \%$ under better control conditions (70\% of theoretical yield). ${ }^{8,9,23}$

Segetis Inc., a company purchased in 2016 by GFBiochemicals, uses a more elaborate process for producing LA as opposed to Biofine (Figure 7). ${ }^{23,117} \mathrm{~A}$ higher concentration of acid in the initial mixture (between $20 \%$ and $80 \%$ of the mixture) results in a faster reaction with lower production of unwanted humins and other byproducts. Besides, the reaction can be performed at temperatures between $90{ }^{\circ} \mathrm{C}$ and $160{ }^{\circ} \mathrm{C}$, lower temperatures than those of the Biofine process. With these operational conditions, humins become suspended on the liquid media, easing separation. However, the high concentration of mineral acid makes it difficult to separate it from FA and LA. At low acid concentrations, a neutralization with a base and consequent formation of salts is made, which would be unfeasible for high concentrations. Therefore, Segetis Inc. developed a process of liquid-liquid extraction with an organic solvent. ${ }^{55}$ The counterpoint to these improvements is that, at high concentrations of mineral acid, the possibility of corrosion becomes a concern, being necessary to use more resistant materials and alloys of higher cost. ${ }^{1,8}$

\section{CONCLUSIONS}

Levulinic acid is an important platform molecule for the economics of a biorefinery and substitution of fossil fuels by renewable raw materials, considering that there is a great diversity of biomasses that can be hydrolyzed. LA presents applications in agriculture, pharmaceuticals, cosmetics, and food additives; and the competitiveness of the innovated industrial process depends on production cost reduction with technological innovation and upscaling. LA industrial production processes from biomass currently use homogeneous reactions, having hydrochloric or sulfuric acid as catalysts, though heterogeneous catalysts have demonstrated to also be active and selective, even using biomass residue as feedstock. The use of ionic liquids faces economic and technological barriers due to the high cost of ILs, longer reaction time, and higher operating costs of separation and recycling when compared to catalytic processes. Among the laboratory studies, high yields obtained with heterogeneous (RG of up to $49 \%$ ) and homogeneous catalysts (RG of up to $51.5 \%$ ) are highlighted, using low-cost agricultural residues such as rice straw, corn cob, corn straw, and sugar cane bagasse. Bench studies demonstrated that ILs possess a potential for LA production, reaching RG values of up to $62.2 \%$ using rice straw, and $53.5 \%$ with Crotalaria juncea fibers, thus being able to be pointed as a perspective for one-pot process development. These experiments, although carried 
out on a laboratory scale, are important to indicate the possible routes and perspectives for expanding LA production to commercial scale.

\section{ACKNOWLEDGEMENTS}

The authors would like to thank for the financial support provided by the Conselho Nacional de Desenvolvimento Científico e Tecnológico - CNPq, and the Fundação de Amparo à Pesquisa do Estado da Bahia - FAPESB, besides support from the Coordenação de Aperfeiçoamento de Pessoal de Nível Superior - Brasil (CAPES) - Financing code 001.

\section{REFERENCES}

1. Khan, A. S.; Man, Z.; Bustam, M. A.; Kait, C. F.; Nasrullah, A.; Ullah, Z.; Sarwono, A.; Ahamd, P.; Muhammad, N.; J. Clean. Prod. 2018, 170, 591.

2. Melo, F. C. D.; Souza, R. F. D.; Coutinho, P. L. A.; Souza, M. O. D.; J. Braz. Chem. Soc. 2014, 25, 2378.

3. Goldemberg, J.; Quim. Nova 2009, 32, 582.

4. Rodrigues, J. A. R.; Quim. Nova 2011, 34, 1242.

5. Ribeiro, P. R.; Carvalho, J. R. M.; Geris, R.; Queiroz, V.; Fascio, M.; Quim. Nova 2012, 35, 1046.

6. Amoah, J.; Kahar, P.; Ogino, C.; Kondo, A.; Biotechnol. J. 2019, 14, 1.

7. Fraga, G. D. V.; Ruy, A. D. S.; Pontes, L. A. M.; Campos, L. M. A.; Teixeira, L. S. G.; Quim. Nova 2020, 43, 631.

8. Weingarten, R.; Cho, J.; Xing, R.; Conner, W. C.; Huber, G. W.; ChemSusChem 2012, 5, 1280

9. Fitzpatrick, S. W.; US Pat. US5608105A 1997.

10. Bevilaqua, D. B.; Rambo, M. K. D.; Rizzetti, T. M.; Cardoso, A. L.; Martins, A. F.; J. Clean. Prod. 2013, 47, 96.

11. Wang, C.; Zhang, Q.; Chen, Y.; Zhang, X.; Xu, F.; ACS Sustain. Chem. Eng. 2018, 6, 3154.

12. Ferreira, V. F.; Silva, F. C. D.; Ferreira, P. G.; Quim. Nova 2013, 36, 1514.

13. Levulinic Acid Market - Global Industry Trends and Forecast to 2027 I Data Bridge Market Research, available at https://www. databridgemarketresearch.com/reports/global-levulinic-acid-market, accessed May 2021.

14. Clauser, M.; Felissia, F. E.; Area, M. C.; Vallejos, M. E.; J. Clean. Prod. 2020, 257, 1 .

15. Badgujar, K. C.; Wilson, L. D.; Bhanage, B. M.; Renewable Sustainable Energy Rev. 2019, 102, 266.

16. Global Levulinic acid Market Information: by technology (acid hydrolysis production process, biofine), by the application (food additive, pharmaceuticals, cosmetic \& personal care and others) and region - forecast till 2027, available at https://www. marketresearchfuture.com/reports/levulinic-acid-market-1639, accessed at May 2021.

17. Levulinic Acid Market: Global Industry Trends, Share, Size, Growth, Opportunity and Forecast 2020-2025, available at https://www. researchandmarkets.com/reports/5021736/levulinic-acid-market-globalindustry-trends, accessed at May 2021.

18. Silva, J. F. L.; Grekin, R.; Mariano, A. P.; Maciel Filho, R.; Energy Technol. 2018, 6, 613 .

19. Mukherjee, A.; Dumont, M. J.; Raghavan, V.; Biomass Bioenergy 2015, 72,143 .

20. Timokhin, B. V.; Baransky, V. A.; Eliseeva, G. D.; Russ. Chem. Rev. 1999, 68, 73 .

21. Mika, L. T.; Cséfalvay, E.; Németh, Á.; Chem. Rev. 2018, 118, 505.

22. Cheng, J. J.; In Biomass to Renewable Energy Processes; Cheng, J. J., org.; CRC Press: Boca Raton, 2018; p. 2.

23. Girisuta, B.; Heeres, H. J.; In Production of Platform Chemicals from
Sustainable Resources; Fang, Z.; Smith Jr, R. L.; Qi, X., orgs.; Springer: Singapore, 2017; pp. 143-169.

24. Werpy, T.; Petersen, G.; U.S. Dep. Energy 2004, 1, 76.

25. Bozell, J. J.; Petersen, G. R.; Green Chem. 2010, 12, 539.

26. Headley, A. D.; In Sustainable Catalysis in Ionic Liquids; Lozano, P., Org.; CRC Press: Boca Raton, 2019; p. 33.

27. Ramli, N. A. S.; Amin, N. A. S.; Bioenergy Res. 2020, 13, 693.

28. Nations, U.; World Food and Agriculture - Statistical Pocketbook 2019; FAO Statistcs: Rome, 2020.

29. Kang, S.; Fu, J.; Zhang, G.; Renewable Sustainable Energy Rev. 2018, $94,340$.

30. Datta, D.; Uslu, H.; J. Mol. Liq. 2017, 234, 330.

31. Morone, A.; Apte, M.; Pandey, R. A.; Renewable Sustainable Energy Rev. 2015, 51, 548.

32. Girisuta, B.; Dussan, K.; Haverty, D.; Leahy, J. J.; Hayes, M. H. B.; Chem. Eng. J. 2013, 217, 61.

33. Galletti, A. M. R.; Antonetti, C.; Ribechini, E.; Colombini, M. P.; Di Nasso, N. N. O.; Bonari, E.; Appl. Energy 2013, 102, 157.

34. Fleig, O. P.; Savioli, E.; Ccopa, E.; Maciel, R.; Plazas, L.; Process Biochem. 2018, 65, 146.

35. Elumalai, S.; Agarwal, B.; Sangwan, R. S.; Bioresour. Technol. 2016, $218,232$.

36. Kumar, S.; Ahluwalia, V.; Kundu, P.; Sangwan, R. S.; Kansal, S. K.; Runge, T. M.; Elumalai, S.; Bioresour. Technol. 2018, 251, 143.

37. Szabolcs, Á.; Molnár, M.; Dibó, G.; Mika, L. T.; Green Chem. 2013, 15, 439.

38. Sweygers, N.; Dewil, R.; Appels, L.; Waste Biomass Valorization 2018 , $9,343$.

39. Zhang, X.; Zhang, X.; Sun, N.; Wang, S.; Wang, X.; Jiang, Z.; Renewable Energy 2019, 141, 802.

40. Girisuta, B.; Danon, B.; Manurung, R.; Janssen, L. P. B. M.; Heeres, H. J.; Bioresour. Technol. 2008, 99, 8367.

41. Liang, C.; Hu, Y.; Wang, Y.; Wu, L.; Zhang, W.; Process Biochem. 2018, 73,124 .

42. Fachri, B. A.; Abdilla, R. M.; Bovenkamp, H. H. V. De; Rasrendra, C. B.; Heeres, H. J.; ACS Sustainable Chem. Eng. 2015, 3, 3024.

43. Kim, H. S.; Kim, S. K.; Jeong, G. T.; J. Ind. Eng. Chem. 2018, 63, 48.

44. Shen, Y.; Xu, Y.; Sun, J.; Wang, B.; Xu, F.; Sun, R.; Catal. Commun. 2014, 50, 17.

45. Rackemann, D. W.; Bartley, J. P.; Doherty, W. O. S.; Ind. Crops Prod. 2014, 52, 46.

46. Yang, F.; Fu, J.; Mo, J.; Lu, X.; Energy Fuels 2013, 27, 6973.

47. Weiqi, W.; Shubin, W.; Chem. Eng. J. 2017, 307, 389.

48. Liu, C.; Feng, Q.; Yang, J.; Qi, X.; Bioresour. Technol. 2018, 255, 50.

49. Galletti, A. M. R.; Antonetti, C.; De Luise, V.; Licursi, D.; Di Nasso, N. N. O.; Bioresouces.com 2012, 7, 1824.

50. Kang, S.; Yu, J.; Biomass Bioenergy 2016, 95, 214.

51. Chen, S. S.; Wang, L.; Yu, I. K. M.; Tsang, D. C. W.; Hunt, A. J.; Jérôme, F.; Zhang, S.; Ok, Y. S.; Poon, C. S.; Bioresour. Technol. 2018, 247, 387.

52. Dutta, S.; Yu, I. K. M.; Tsang, D. C. W.; Su, Z.; Hu, C.; Wu, K. C. W.; Yip, A. C. K.; Ok, Y. S.; Poon, C. S.; Bioresour. Technol. 2020, 298, 122544.

53. Hurst, G.; Brangeli, I.; Peeters, M.; Tedesco, S.; Chem. Pap. 2020, 74, 1647.

54. Kim, H. S.; Park, M. R.; Kim, S. K.; Jeong, G. T.; Korean J. Chem. Eng. 2018, 35, 1290

55. Mullen, B. D.; Yontz, D. J.; Leibig, C. M.; US Pat. US9073841B2 2015

56. Filiciotto, L.; Balu, A. M.; Van der Waal, J. C.; Luque, R.; Catal. Today 2018, 302, 2.

57. Jung, D.; Körner, P.; Kruse, A.; Biomass Convers. Biorefin. 2019.

58. Mija, A.; van der Waal, J. C.; Pin, J. M.; Guigo, N.; de Jong, E.; Constr. Build. Mater. 2017, 139, 594. 
59. Hayes, D. J.; Fitzpatrick, S.; Hayes, M. H. B.; Ross, J. R. H.; Biorefineries - Industrial Processes and Products: Status Quo and Future Directions 2008, 1, 139.

60. MilliporeSigma | United States I Sigma-Aldrich, available at https:// www.sigmaaldrich.com/, accessed at May 2021.

61. Halder, P.; Kundu, S.; Patel, S.; Setiawan, A.; Atkin, R.; Parthasarthy, R.; Paz-Ferreiro, J.; Surapaneni, A.; Shah, K.; Renewable Sustainable Energy Rev. 2019, 105, 268.

62. Zhou, D.; Shen, D.; Lu, W.; Song, T.; Wang, M.; Feng, H.; Shentu, J.; Long, Y.; Molecules 2020, 25, 1.

63. Sobreira, T.; da Silva, L.; de Menezes, F.; França, E.; Aquino, K.; Quim. Nova 2020, 43, 1.

64. Thomas, M. S.; Koshy, R. R.; Mary, S. K.; Thomas, S.; Pothan, L. A.; In Springer Briefs in Molecular Science Biobased Polymers; Le Moigne, N., ed.; Springer: Cham, 2019; p. 6.

65. Nations, U.; The State of World fisheries and aquaculture, Rome, 2020.

66. Alonso, D. M.; Wettstein, S. G.; Dumesic, J. A.; Green Chem. 2013, 15, 584.

67. Gallo, J. M. R.; Alamillo, R.; Dumesic, J. A.; J. Mol. Catal. A: Chem. 2016, 422, 13.

68. Joshi, S. S.; Zodge, A. D.; Pandare, K. V.; Kulkarni, B. D.; Ind. Eng. Chem. Res. 2014, 53, 18796.

69. Peng, L.; Lin, L.; Zhang, J.; Zhuang, J.; Zhang, B.; Gong, Y.; Molecules 2010, 15, 5258

70. Zuo, Y.; Zhang, Y.; Fu, Y.; ChemCatChem 2014, 6, 753.

71. Xiang, M.; Liu, J.; Fu, W.; Tang, T.; Wu, D.; ACS Sustainable Chem. Eng. 2017, 5, 5800.

72. Xu, Y.; Liu, G.; Fu, J.; Kang, S.; Xiao, Y.; Yang, P.; Liao, W.; Biomass Convers. Biorefin. 2019, 9, 609 .

73. Feng, J.; Tong, L.; Xu, Y.; Jiang, J.; Hse, C.; Yang, Z.; Pan, H.; Ind. Crops Prod. 2020, 145, 112084.

74. Qing, Q.; Guo, Q.; Wang, P.; Qian, H.; Gao, X.; Zhang, Y.; Bioresour. Technol. 2018, 260, 150.

75. Kimura, V. T.; Poço, J. G. R.; Matsubara, R. M. S.; Derenzo, S.; Gomes, D. Z.; Marcante, A.; Braz. J. Dev. 2019, 5, 14804.

76. Lawagon, C. P.; Faungnawakij, K.; Srinives, S.; Thongratkaew, S.; Chaipojjana, K.; Smuthkochorn, A.; Srisrattha, P.; Charinpanitkul, T.; Catal. Today 2020, 1.

77. Pizzolitto, C.; Ghedini, E.; Menegazzo, F.; Signoretto, M.; Giordana, A.; Cerrato, G.; Cruciani, G.; Catal. Today 2020, 345, 183.

78. Thapa, I.; Mullen, B.; Saleem, A.; Leibig, C.; Baker, R. T.; Giorgi, J. B.; Appl. Catal. A 2017, 539, 70.

79. Upare, P. P.; Yoon, J. W.; Kim, M. Y.; Kang, H. Y.; Hwang, D. W.; Hwang, Y. K.; Kung, H. H.; Chang, J. S.; Green Chem. 2013, 15, 2935.

80. Sun, Z.; Wang, S.; Wang, X.; Jiang, Z.; Fuel 2016, 164, 262.

81. Weiqi, W.; Wu, S.; Fuel 2018, 225, 311.

82. Liu, Y.; Li, H.; He, J.; Zhao, W.; Yang, T.; Yang, S.; Catal. Commun. 2017, 93, 20.

83. Ramli, N. A. S.; Amin, N. A. S.; Chem. Eng. J. 2016, 283, 150.

84. Park, M. R.; Kim, S. K.; Jeong, G. T.; J. Ind. Eng. Chem. 2018, 61, 119.

85. Huang, X.; Kudo, S.; Sperry, J.; Hayashi, J. I.; ACS Sustain. Chem. Eng. 2019, 7, 5892

86. Li, X.; Xu, R.; Liu, Q.; Liang, M.; Yang, J.; Lu, S.; Li, G.; Lu, L.; Si, C.; Ind. Crops Prod. 2019, 141, 111759.
87. Zhi, Z.; Zheng, X.; Gu, X.; Li, X.; Zhang, R.; Lu, X.; Fuel 2015, 76, 672.

88. Omari, K. W.; Besaw, J. E.; Kerton, F. M.; Green Chem. 2012, 14, 1480

89. Velaga, B.; Parde, R. P.; Soni, J.; Peela, N. R.; Microporous Mesoporous Mater. 2019, 287, 18

90. Liu, C.; Wei, M.; Wang, F.; Wei, L.; Yin, X.; Jiang, J.; Wang, K.; J. Energy Inst. 2020, 93, 1642.

91. Wang, C.; Yang, G.; Zhang, X.; Shao, L.; Lyu, G.; Mao, J.; Liu, S.; Xu, F.; Cellulose 2019, 26, 8313.

92. Song, J.; Li, Y.; Zhang, X.; Zhang, D.; Jiang, Z.; Wang, X.; BioResources 2020, 15, 240.

93. Zhong, J.; Pérez-Ramírez, J.; Yan, N.; Green Chem. 2021, 23, 18.

94. Sun, Z.; Duan, X. X.; Gnanasekarc, P.; Yan, N.; Shi, J.; Biomass Convers. Biorefin. 2020.

95. Li, X.; Lu, X.; Nie, S.; Liang, M.; Yu, Z.; Duan, B.; Yang, J.; Xu, R.; Lu, L.; Si, C.; Ind. Crops Prod. 2020, 145.

96. Ramli, N. A. S.; Amin, N. A. S.; Bioenergy Res. 2017, 10, 50.

97. Elgharbawy, A. A.; Alam, M. Z.; Moniruzzaman, M.; Goto, M.; Biochem. Eng. J. 2016, 109, 252.

98. Rodriguez, H.; In Ionic Liquids for Better Separation Processes; Rodriguez, H., Org.; Springer: New York, 2015; p. 3.

99. Ozokwelu, D.; Zhang, S.; Okafor, O. C.; Cheng, W.; Litombe, N.; In Novel Catalytic and Separation Processes Based on Ionic Liquids; Elsevier: Amsterdam, 2017; pp. 1.

100. Zhou, J.; Sui, H.; Jia, Z.; Yang, Z.; He, L.; Li, X.; RSC Adv. 2018, 8, 32832.

101. Shen, Y.; Sun, J. K.; Yi, Y. X.; Wang, B.; Xu, F.; Sun, R. C.; Bioresour. Technol. 2015, 192, 812.

102. Khan, A. S.; Man, Z.; Bustam, M. A.; Nasrullah, A.; Ullah, Z.; Sarwono, A.; Shah, F. U.; Muhammad, N.; Carbohydr. Polym. 2018, 181, 208.

103. Ya'aini, N.; Amin, N. A. S.; BioResources 2013, 8, 5761.

104. Tiong, Y. W.; Yap, C. L.; Gan, S.; Yap, W. S. P.; J. Clean. Prod. 2017, $168,1251$.

105. Tulaphol, S.; Hossain, M. A.; Rahaman, M. S.; Liu, L. Y.; Phung, T. K.; Renneckar, S.; Grisdanurak, N.; Sathitsuksanoh, N.; Energy Fuels 2020, 34, 1764.

106. Liu, L.; Li, Z.; Hou, W.; Shen, H.; Carbohydr. Polym. 2018, 181, 778.

107. Ren, H.; Zhou, Y.; Liu, L.; Bioresour. Technol. 2013, 129, 616.

108. Ren, H.; Girisuta, B.; Zhou, Y.; Liu, L.; Carbohydr. Polym. 2015, 117 , 569.

109. Paul, S. K.; Chakraborty, S.; Bioresour. Technol. 2018, 253, 85.

110. Alipour, S.; Omidvarborna, H.; J. Clean. Prod. 2017, 143, 490.

111. Ramli, N. A. S.; Amin, N. A. S.; J. Mol. Catal. A: Chem. 2015, 407, 113.

112. Kumar, K.; Pathak, S.; Upadhyayula, S.; J. Clean. Prod. 2020, 256, 120292.

113. Hou, W.; Zhao, Q.; Liu, L.; Green Chem. 2020, 22, 62.

114. Hou, W.; Liu, L.; Shen, H.; Carbohydr. Polym. 2018, 195, 267.

115. Garkoti, C.; Shabir, J.; Mozumdar, S.; New J. Chem. 2017, 41, 9291.

116. Belchior, D. C. V.; Duarte, I. F.; Freire, M. G.; In Application of Ionic Liquids in Biotechnology; Itoh, T., Koo, Y.-M., orgs.; Springer: Cham, 2019; p. 2.

117. GFBiochemicals, available at http://www.gfbiochemicals.com/ company/, accessed at May 2021. 